GEOFF GOODWIN ${ }^{1}$

\title{
Communal struggles for water through coproduction: Pandemic experiences in Highland Ecuador in historical perspective ${ }^{2}$
}

\section{Introduction $^{3}$}

Covid-19 has exposed acute water inequalities within and between countries. Handwashing is widely seen as one of the most effective measures for preventing the spread of the virus. Yet more than two billion people lack sufficient access to clean water to carry out this basic task. Hundreds of millions of small-scale farmers also lack reliable access to irrigation water, making them extremely

\footnotetext{
${ }^{1}$ Geoff Goodwin is a Guest teacher at the Department of International Development, in London School of Economics (LSE). Geoff is an interdisciplinary political economist who draws insights from political economy, geography, anthropology, sociology, and history.

2 This article was originally published in http://www.alternautas.net/blog/2021/7/28/communalstruggles-for-water-through-coproduction-pandemic-experiences-in-highland-ecuador-inhistorical-perspective

${ }^{3}$ This essay draws on interviews with representatives of community water associations, social movements, political parties, local governments, state bureaucracies and non-governmental organisations. 58 semi-structured interviews and extended discussions were conducted between 2015 and 2019 and a further 30 shorter interviews were conducted between February and April 2021. The bulk of these interviews were undertaken in the highland region of Ecuador, but some interviews and visits were also conducted in the coastal region. Most of the community water associations included in this research are located in rural and peri-urban areas. The essay also draws on extensive legal and newspaper archive materials, participation in public and communal meetings, personal observations, informal conversations, and fieldnotes. I am extremely grateful to everyone who participated in this research and to Ximena Caiza for superb research assistance during the pandemic. Funds secured through RIIF at the Department of International Development at the London School of Economics have supported this research since 2015. Thanks also to two Alternautas referees for their insightful comments on an earlier draft and to Johannes Waldmuller and Emilie Dupuits for encouraging me to write this essay. I am solely responsible for all opinions, errors, and omissions.
} 
vulnerable to seasonal and climatic changes in water supply. The crisis triggered by the Covid-19 pandemic has exacerbated water inequalities as economic activity has collapsed, government revenues have plunged, and poverty has soared.

In this context, approaches to water services that create space for water users to secure collective control of local water supplies take on renewed importance. Coproduction allows room for this. Supplying water through coproduction involves water users and associations taking collective responsibility for the delivery of water services while receiving support from various other actors, including local governments, state bureaucracies, social movements, and nongovernmental organizations (McMillan et al, 2014; Moretto et al, 2018; Goodwin, 2019). Coproduction therefore differs to public and private water services and to public-private partnerships, which are contract based and explicitly orientated towards profit-making ${ }^{4}$. Water delivered through coproduction can support multiple daily activities, including drinking, cleaning, washing, cooking, and irrigation. Yet coproduction is not simply about supplying water. New political subjects, relations, and institutions emerge through the process, generating political tensions and opportunities at multiple scales (Mitlin, 2008; Goodwin, 2019; Dupuits, 2021). Coproduction also provides a basis for the exchange and production of knowledge and tensions can also emerge around this aspect of the process (Llano-Arias, 2015). Hence, coproduction is intrinsically political.

I will demonstrate this by sketching the history of coproduced water services in highland Ecuador and illustrating the political changes and struggles that have occurred through this process. I will then briefly discuss the initial impact of the Covid-19 pandemic, focusing on community water associations, the protagonists in coproduced water services in Ecuador.

\section{A potted history of coproduced water services in Ecuador}

Neoliberalism is generally seen as the starting point for the coproduction of public goods and services in the Global South (Joshi and Moore, 2004). However,

\footnotetext{
${ }^{4}$ For further insight into the coproduction of public goods and services in the Global South, see Joshi and Moore (2004), Mitlin (2008), Mitlin and Bartlett (2018), Moretto et al (2018), and Goodwin (2019.)
} 


\section{Alternautas 8 (1) - July 2021}

coproduction has longer historical roots in Latin America, and these diverse histories are central to understanding contemporary political dynamics in the region (Goodwin, 2019). The history of coproduced water services in Ecuador shows coproduction can provide a basis for alternative approaches to water services based on communal relations and practices and create a platform to transform the wider legal and bureaucratic framework that regulates water at multiple scales. Yet coproduction is also a contested process and political struggles have occurred around various dimensions in Ecuador, especially the autonomy of water associations and the authority of the state.

In this section, I will outline the history of coproduced water services in highland Ecuador in three phases: i) the development of the state water bureaucracy and the increase of community organizing in the 1960s and $1970 \mathrm{~s}$ ii) the implementation of structural adjustment and neoliberal reforms and the proliferation of non-governmental organisations and international development agencies in the 1980s and 1990s and iii) the strengthening of the state and the resistance of community water associations in the 2000 s and $2010 \mathrm{~s}^{5}$.

Coproduced water services started to spread in Ecuador in the 1960s and 1970s as civilian and military governments introduced a series of reforms that reconfigured water relations and institutions. The Instituto Ecuatoriano de Obras Sanitarias was formed in 1965 to deliver drinking water and sanitation to rural and urban communities, replacing the Servicio Cooperativo Interamericano de Salud Publica, which was established in the 1940s and part funded by the United States government. Shortly afterwards, the Instituto Ecuatoriano de Recursos Hidráulicos was established to regulate water on a national scale (Armijos, 2012; Hoogesteger, 2015). Meanwhile, tax reforms, overseas loans, and oil revenues gave the state greater capacity to invest in water infrastructure and services, especially in the 1970s. Drinking water systems were constructed and extended in towns and cities across the highlands, while public investment was increased in drinking and irrigation systems in rural areas. However, the coverage of potable and irrigation systems remained limited and community mobilization was required to overcome water scarcity and expand water services. The

\footnotetext{
5 The analysis presented in this and the following section draws heavily on Goodwin (2019) - refer to this article for more empirical detail and theoretical discussion. See also Goodwin (2021b).
} 
transformation of the agrarian political economy, particularly the gradual collapse of the traditional hacienda complex, created greater room for autonomous community organizing in rural areas (Goodwin, 2017, 2021ab). Meanwhile, the informal settlements that emerged on the fringes of rapidly expanding towns and cities provided fertile terrain for organizing through water. Water legislation introduced during this period lent additional support to communal organization, especially the Ley de Aguas (1972) and Ley de Juntas Administradoras de Agua Potable y Alcantarillado (1979).

Coproduced water services spread as rural and peri-urban communities increasingly interacted with state and non-state actors to improve access to water ${ }^{6}$. Relations and actors varied from case to case, but a general pattern started to emerge which remains broadly intact today: community members contributed labour, finance and local knowledge, while state agencies, local governments, non-governmental organisations, and development agencies provided raw materials, machinery, and technical knowledge.

Community members generally formed associations to manage water and deliver services over the long run, often integrating several communities into a single association. Sometimes, however, water services were organised through existing rather than newly established organizations ${ }^{7}$. The burden of delivering water services has been too great for some associations, which have collapsed under the strain, and many others have experienced significant operational problems. Nonetheless, community water associations have performed a crucial role in supply water to low-income families and small-scale farmers in the highland region since the 1960s and 1970s.

The basic pattern of coproduced water services established during this period remained in place in the 1980s and 1990s. However, coproduction dynamics

\footnotetext{
${ }^{6}$ For examples of coproduction in the local and national press from the 1960s and 1970s, see, for example, 'Misión Andina dará servicio de agua a 20.000 campesinos', December 13 1968, El Comercio, p. 20 and 'Familias aportan con 300 sucres para construcción de un sistema de agua potable', June 17 1972, El Espectador, pp. 1-6.

${ }^{7}$ In this essay, I use the term 'community water association' to capture the broad range of water user organisations indicated above, which in Ecuador, are usually called juntas del agua or sistemas comunitarios del agua. This includes organisations that manage drinking and irrigation water. The number of members integrated into community water associations ranges from less than 50 to more than 10,000 and each association has its own history and characteristics.
} 
shifted as right-wing and centre-left civilian governments implemented structural adjustment and neoliberal reforms, slashed public spending, and reorganised state water bureaucracies. Water associations proliferated as state support for drinking and irrigation water systems declined and state-operated irrigation systems were transferred to farmers to manage (FRH, 2011; Andolina, 2012; Hoogesteger, $2013)^{8}$. With limited access to public funds, communities and associations increasingly turned to multilateral organizations, overseas development agencies, and non-governmental organizations to help construct or improve water systems. Community members continued to take collective responsibility for the day-today delivering of water services over the long run. However, this diverse set of national and international actors made important contributions, including finance, materials, machinery, and technical knowledge (Hoogesteger, 2014, 2015, 2016; Dupuits, 2019, 2021; Goodwin, 2019, 2021b).

The state was not absent from this process. Water legislation, though only loosely enforced, continued to support the establishment of water associations, while state water bureaucracies, however enfeebled, continued to regulate water use and distribution at multiple scales (Pacari, 1998; Cremers et al, 2005; Hoogesteger et al, 2017). Moreover, state agencies and local governments continued to work directly with rural and peri-urban communities to construct and develop water systems, and public water companies also contributed in some cases. Yet the composition of actors involved in coproduction changed in the 1980s and 1990s, with the state making fewer contributions and non-state actors taking a more prominent role (Goodwin, 2019).

Coproduction dynamics shifted again in the 2000s and 2010s when Rafael Correa came to power and initiated the so-called revolución ciudadana - a state-centric capitalist political project, which broke with the neoliberal orthodoxy (Becker, 2012; Martínez Novo, 2014) $)^{9}$. Public spending on water infrastructure and

\footnotetext{
${ }^{8}$ For examples of coproduction in the local and national press from the 1980s and 1990s see, for example, 'Abastecimiento de agua de consumo de inauguró en Miraflores Cochapamba', August 4 1981, El Espectador, p. 7, 'Minga para dotar de agua a comunidades de Salcedo', July 2 1982, El Comercio, p. B-10, and 'Agua potable para tres comunidades campesinas', June 11 1988, El Comercio, p. A-8.

${ }^{9}$ For examples of coproduction in the local and national press from the 2000s and 2010s, see, for instance, 'Con iniciativa logran mejor acceso al agua', August 26 2017, El Universo and 'Las Nieves y La Chonta mejorarán sistema de agua', December 21 2018, El Tiempo.
} 
services increased, albeit from a very low base, and the 2008 constitution was introduced, which included important declarations on water, including proscribing privatization, entrusting water management to the state and community, promoting public-community alliances to deliver water services, and declaring water as a human right. Following the introduction of the new constitution and a protracted political struggle, a comprehensive new water law - Ley Orgánica de Recursos Hídricos, Usos y Aprovechamiento del Agua (2014) - was promulgated, which replaced existing water legislation and laid the legal foundations for a new water regime (Goodwin, 2019).

By entrusting water management to the state and community and promoting public-community alliances to deliver water services, the new regime effectively formalized coproduced water services, integrating water associations, local governments and state agencies into a legal and bureaucratic framework, while leaving the precise contributions and roles of the various actors involved largely undefined and open to negotiation (Joshi and Moore, 2004). The constitution and law reflected the history of coproduction and incorporated some of the historical demands of community water associations and social movements. However, the state was given a central role in the new regime and decision-making was concentrated in new water bureaucracies - Secretaría Nacional de Agua (SENAGUA) and the Agencia de Regulación y Control de Agua (ARCA). This threatened the autonomy of community water associations and generated political tensions and struggles. The next section briefly discusses these struggles.

\section{Coproduction politics during the revolución ciudadana}

Coproduction reconfigures state-society relations and creates new political subjects, relations, and institutions. In doing so, it generates political struggles and opportunities at multiple scales. The reason for this lies partly in its tendency to promote engagement with and autonomy from the state (Goodwin, 2019).

The form, quantity, and frequency of contributions to coproduction mediate this relationship (Goodwin, 2019). Here, the active role community water associations have performed in developing and maintaining potable and irrigation water systems and delivering water services in highland Ecuador has been crucial. The 
general process - as outlined above - involves members of water associations contributing labour, finance, and knowledge to the construction, maintenance, and management of water systems. Thus, most associations have made significant contributions over the long-run, which has given them a strong sense of collective ownership and control.

Labour contributions have been especially important. In the highland region, the bulk of the labour community members have contributed to the construction and maintenance of water systems is organised through the Andean collective labour practice, the minga (Boelens and Doornbos, 2001; Armijos, 2013). Labour contributed through mingas is not remunerated in cash, but food, drink and festivities are frequently provided. Water rights are often established and maintained through participation in mingas, and the practice, though certainly not free of conflict and dispute, underpins communal relations (Vos and Boelens, 2015; Hidalgo et al, 2017). In addition to collective labour contributed through mingas, members also voluntarily contribute labour to the management of water systems and some water associations also recruit members as waged operators, engineers, and administrators.

Struggles over the construction and implementation of the new water regime during the revolución ciudadana illustrate the political salience of this aspect of coproduction (Goodwin, 2019). The series of new regulations that the regime imposed on water associations was one of the main sources of tension. Faced with greater state regulation and control, water associations and social movements resisted, drawing attention to how community water systems were constructed historically.

Yaku Pérez Guartambel, the leader of a coalition of community water systems in the southern highlands and the then president of the highland indigenous movement, Ecuarunari, made this point forcefully:

Was it the Correa government or the Secretary of Water or the hundreds and thousands of mingueros who organized through water to construct community systems? ${ }^{10}$

\footnotetext{
10 'Cuestionan instructivo sobre los sistemas comunitarios de agua', July 06 2016, El Mercurio, p.
} 3-A. 
Although Pérez downplays the historical contributions of state agencies, local governments, and non-governmental organisations to this process, there is substantial evidence to support his claim that mingueros have performed a vital role in developing water systems and infrastructure in the highland region. Several examples are documented in the literature. For instance, Boelens and Doornbos (2001) explain how indigenous communities in Ceceles, Chimborazo laboured collectively to construct a new irrigation canal platform in the early 1990s. Meanwhile, Hidalgo et al (2017) illustrate the importance of mingas in the construction and maintenance of irrigation networks in Tabacundo, Pichincha. The centrality of mingas was also stressed throughout my fieldwork in the highlands. For example, the president of a small water association in Palmira, Chimborazo explained how its members recently constructed a new irrigation system:

We used our own labour power...we organized a minga with the participation of men, women and children...to build the system. We carried gravel, sand and cement on our backs and sometimes on animals...this process lasted three years, all of it based on participation in the minga. ${ }^{11}$

National and local newspaper archives provide additional evidence. For instance, El Comercio reports in the early 1970s:

Five hundred and twenty-nine kilometres of irrigation channels and eighty-three kilometres of access routes have been constructed in the country through the unpaid system of communitarian work called the minga. ${ }^{12}$

These sources highlight the considerable collective labour power that communities and associations have invested into water systems and hydraulic infrastructure across generations. Through these physical endeavours, new subjectivities, practices and relations have been formed, which have generated a strong sense of collective ownership and control. The day-to-day collective

\footnotetext{
${ }^{11}$ Interview: President, Junta de Riego Palmira, Palmira, August 222017.

12 '529 kms de canales de riego construidos mediante mingas', February 28 1972, El Comercio, pp. 1 and 12.
} 


\section{Alternautas 8 (1) - July 2021}

running of water services and participation in community assemblies have added to this.

Together, these factors have generated a strong basis for collective autonomy (Armijos, 2013; Dinerstein, 2015; Goodwin, 2019, 2021b). The practice and meaning of autonomy vary between community water associations. In some cases, it is a rejection of state power and authority, which complicates but does not preclude coproduction. In others, it is better understood as a response to state neglect and incompetence. Regardless of its specific origins and forms, autonomy provides water associations with the capacity to take decisions over various aspects of water management and services, including water distribution, organizational structures, water tariffs, and infrastructure. The minga supports this by enabling associations to construct and maintain infrastructure, reduce reliance on the state, and strengthen communal relations and collective water rights. However, it is not a precondition for autonomy and some associations, especially in the coastal region, operate with a high level of operational autonomy without using the practice.

Community water association autonomy is gradational, with some associations having greater autonomous capacity than others, and scalar, insofar as it operates at different levels, with some associations integrating smaller organizations, which retain a relatively high degree of autonomous control over water at the community level. In these cases, autonomy is negotiated within the association as well as between the association and the state. While collective autonomy underpins water services, as indicated above, it certainly cannot be reduced to this domain. The practice has enabled communities and associations to carve out space for the control of land and water, develop alternative political practices and relations, and renegotiate their relationship with the state (Armijos, 2013; Goodwin, 2021b). Thus, autonomy is a heterogenous and multifaceted political practice, which reconfigures power and authority and creates new political subjects and relations.

Historical changes in the composition of actors involved in coproduction has had a significant bearing on community water associations autonomy. Increased participation of overseas development agencies, multilateral institutions and nongovernment organizations in the 1980s and 1990s reduced the reliance of water 
associations on the state and increased space for them to develop autonomous capacity. With cash-strapped state agencies and local governments contributing less funding, materials and technical knowledge, water associations reduced their engagement with the state and strengthened their ties with non-state actors. These interactions sometimes threatened collective autonomy as overseas development agencies, multilateral institutions and non-governmental organizations attempted to impose neoliberal practices, norms, and structures on water associations (Andolina, 2012; Hoogesteger, 2015; Dupuits, 2019, 2021). Nonetheless, at the aggregate level, the shift in the composition of coproduction in the 1980s and 1990s generally supported community water association autonomy (Goodwin, 2019, 2021b). When the Correa governments attempted to increase state control of water in the 2000s and 2010s, they were met with staunch resistance from community water associations, which sought to protect the autonomous spaces they had constructed during earlier phases of coproduction.

The end of Rafael Correa's decade in power started a new phase of coproduction politics as his successor, Lenín Moreno, set about dismantling the revolución ciudadana and steering policies back towards the neoliberal orthodoxy. This included slashing public spending and restructuring the state. The US\$ 4.2 billion agreement that the Moreno government agreed with the International Monetary Fund (IMF) in early 2019 gave further impetus to this process and promised a prolonged period of austerity. In efforts to build bridges with water associations and indigenous movements, Moreno recruited prominent indigenous leaders into SENAGUA, which momentarily created opportunities for some water associations to protect their autonomy and strengthen alliances within the state. However, the brutal state repression of protests against the Moreno government in late 2019 saw indigenous bureaucrats resign as indigenous-state relations once again deteriorated (Ponce et al, 2020).

With the prospect of meaningful state support dwindling, water associations started the 2020s even more reliant on autonomous practices and relations to deliver water services and overcome water scarcity. 


\section{Coproduced water services during the Covid-19 pandemic}

The IMF-sponsored austerity politics of the Moreno administration and the failure of the Correa governments to tackle structural problems and inequalities left Ecuador ill-equipped to manage the Covid-19 pandemic.

The virus spread rapidly in Guayaquil in March 2020, overwhelming the city and its fragile public health system, before spreading throughout the country in the following months. The Moreno government closed the country's borders, introduced a national lockdown, and imposed public health regulations to prevent the spread of the virus. However, infection rates remained relatively high in 2020, before spiking again in early 2021 as new variants of the virus arrived in the country, and the Moreno government's highly circumscribed vaccination programme failed to reach a significant proportion of the population. The size of the informal economy, lack of state support, and scale of poverty and inequality contributed to the spread of the virus as most Ecuadorians were left with little choice but to continue working, despite the health risks. The collapse of economic activity, the dismissal of public and private sector workers, and the liberalisation of the labour market have increased precarity: incomes have plunged, poverty has soared, and inequality has deepened (Jara et al, 2021; McBurney et al, 2021).

Water has taken on renewed importance in this context, and coproduced water services have performed a vital role in supplying water to low-income households and small-scale farmers during the pandemic. However, community water associations, the lynchpins of coproduced water services, have experienced significant challenges and undergone important changes as a result of the pandemic. Here, I will briefly discuss four issues, drawing on 30 interviews conducted with representatives of water associations between February and April $2021^{13}$. The following preliminary analysis only offers a brief glimpse into a complex and evolving situation.

The first issue relates to the use and distribution of water. Water use increased during the opening wave of the pandemic as community members spent more time at home and used more water for cooking, cleaning, washing, and irrigation.

\footnotetext{
${ }^{13}$ Ximena Caiza conducted these interviews remotely in Ecuador. I am indebted to Ximena for her excellent research and analysis and to everyone who participated in this research at the most testing of times.
} 
Communal struggles for water $\mid 120$

Unemployment and migration added further pressure as some members of rural communities who lived in towns and cities returned home during the pandemic. Some organizations reported brief water shortages because of these changes, but most expressed relief at having reliable access to drinking and irrigation water. Hence, the pandemic appears to have revalorised the importance of water, which might create a platform for water associations to build on in the wake of the pandemic.

The second issue concerns the diverse infrastructures managed by community water associations. Mingas, as noted above, are fundamental to the construction and maintenance of hydraulic infrastructure in the Andes. However, the social distancing rules introduced to restrict the spread of Covid-19 have limited the use of this practice and forced water associations to use alternatives. In some cases, this has involved hiring machinery and labourers to complete work usually undertaken through mingas or organising smaller socially-distanced groups to undertake emergency repairs. The eruption of Sangay, a towering volcano perched on the eastern fringes of the Andes, presented further infrastructural challenges to some water associations, which undertook emergency works after volcanic ash contaminated their water systems in early 2021. The suspension of payment for the water services provided by water associations during the opening wave of the pandemic and the costs associated with the lack of mingas have left many associations with fewer funds to invest in infrastructure. Some smaller water associations also reported shortages in the chemicals used to treat drinking water, which impacted water quality during the pandemic.

The third issue involves the diverse collective autonomous practices and relations that underpin community water associations. In addition to restricting mingas, social distancing rules have also limited community assembly meetings, which are important spaces for airing grievances, resolving conflicts, and collective decision-making. Social media and digital platforms have been used to help plug the gap left by the lack of meetings. However, some association members lack reliable access to the internet and mobile phones, which appears to have left them at the margin of decision making. Despite these challenges, many water associations have strengthened relations of solidarity and reciprocity during the pandemic (Córdoba, 2021). Continuity in water services has been assured regardless of the ability of members to pay tariffs and charges for extra water use 
have been waived ${ }^{14}$. Tackling the complex organisational challenges presented by the pandemic has also created opportunities to strengthen communal relations and share and extend knowledge.

The fourth issue concerns the relations community water associations have formed with external actors through coproduction. Previously established relations with local and regional governments have been important for some water associations during the pandemic. Yet access to government resources has been uneven, with larger associations that incorporate multiple communities generally better placed to communicate and negotiate with the state. More generally, state support has been complicated by the failure of the central government to transfer funds to local and regional governments during the pandemic. The incorporation of Secretaría Nacional del Agua into the Ministerio del Ambiente and aggressive budget and staff cuts have further reduced space for cooperation. However, several water associations have drawn on support from non-governmental organisations, including Ayuda en Acción, Fondo Ecuatoriano Populorum Progressio (FEPP) and Central Ecuatoriana de Servicios Agrícolas (CESA). Hence, relations and practices formed through coproduction have supported many water associations during the pandemic, even if the IMF-sponsored austerity politics of the Moreno government have limited state support at this crucial time.

\section{Concluding remarks}

Coproduction has created space for water users to take collective control of local water supplies in Ecuador. This historical process, which started to gather pace in the 1960s and 1970s, has seen community water associations develop varying degrees and forms of collective autonomy, allowing them to deliver water services over the long run, with periodic support from various state and non-state actors. Collective autonomous practices and relations have enabled water associations to continue to supply drinking and irrigation water during the Covid-19 pandemic and, in doing so, protect the health and livelihoods of their members and strengthen communal relations. However, water associations have had to shoulder

\footnotetext{
14 Roca-Servat et al (2020) report similar findings in their insightful analysis of acueductos
} comunitarios in Colombia during the Covid-19 pandemic. See also Córdoba et al (2021). 
the costs of dealing with the fallout from the pandemic, which has left them with less funds to invest in infrastructure and services. The short-term prospects of securing significant external support to overcome these challenges are limited. The government of the newly elected right-wing president of Ecuador, Guillermo Lasso, is set to extend the IMF-sponsored liberal austerity policies of his predecessor, Lenín Moreno, which will place definite limits on state support in the near-term. He is also likely to promote the privatisation of water sources and services, which might threaten coproduction. Meanwhile, overseas development agencies and international non-governmental organisations have scaled back operations in Ecuador in recent years and have also experienced significant budget cuts. The pandemic might lead to the rejuvenation and proliferation of these actors. However, in the short-term, at least, the future of coproduced water services will rest even more squarely on the collective autonomous practices and relations of community water associations. History suggests that these factors will weigh heavily on water politics in Ecuador as the country transitions toward its post-pandemic future(s).

\section{References}

Andolina, R. (2012). The Values of Water: Development Cultures and Indigenous Cultures in Highland Ecuador. Latin American Research Review. 47 (2): 3-26

Armijos, M.T. (2012). Negotiating Citizenship Through Communal Water Management in Highland Ecuador. PhD Thesis, University of Sussex

Armijos, M.T. (2013). They Cannot Come and Impose on Us: Indigenous Autonomy and Resource Control Through Collective Water Management in Highland Ecuador. Radical History Review. 116: 86-103

Becker, M. (2012). Building a Plurinational Ecuador: Complications and Contradictions. Socialism and Democracy. 26 (3): 72-92

Boelens, R. and Doornbos, B. (2001). The Battlefield of Water Rights. Rulemaking Amidst Conflicting Normative Frameworks in the Ecuadorian Highlands. Human Organization. 60 (4): 343-355. 
Boelens, R., Hoogesteger, J. and Baud, M. (2015). Water Reform Governmentality in Ecuador: Neoliberalism, Centralization and the Restraining of Polycentric Authority and Community Rule-Making. Geoforum. 64: 281-91

Boelens, R. and Vos, J. (2014). Legal Pluralism, Hydraulic Property Creation and Sustainability: The Materialized Nature of Water Rights in User-Managed Systems. Current Opinion in Environmental Sustainability. 11: 55-62.

Córdoba, D, Peredo, AM, and Chaves, P (2021). Shaping Alternatives to Development: Solidarity and Reciprocity in the Andes during COVID-19. World Development, early view

Cremers, L., Ooijevaar, M. and Boelens, R. (2005). Institutional Reform in the Andean Irrigation Sector: Enabling Policies for Strengthening Local Rights and Water Management. Natural Resources Forum. 29 (1): 37-50.

Dinerstein, A.C. (2015). The Politics of Autonomy in Latin America: The Art of Organizing Hope. Basingstoke: Palgrave Macmillan.

Dupuits, E. (2019). Water Community Networks and the Appropriation of Neoliberal Practices: Social Technology, Depoliticization, and Resistance. Ecology and Society 24 (2): 20

Dupuits, E. (2021). Coproducción de imaginarios sobre justicia hídrica y desarrollo verde en Ecuador. Revista Europea de Estudios Latinoamericanos y del Caribe. 111: 19-37

FRH (2011). Transferencia de competencias de riego para el desarrollo. Quito: Foro de los Recursos Hídricos

FRH (2013). La gestión comunitaria del agua para el consumo humano y el saneamiento en el Ecuador: diagnóstico y propuestas. Quito: Foro de los Recursos Hídricos

Goodwin, G, (2017). The Quest to Bring Land under Social and Political Control: Land Reform Struggles of the Past and Present in Ecuador. Journal of Agrarian Change 17 (3): 571-93 
Communal struggles for water | 124

Goodwin, G. (2019). The Problem and Promise of Coproduction: Politics, History, and Autonomy. World Development 122: 501-513.

Goodwin, G, (2021a). Fictitious Commodification and Agrarian Change: Indigenous Peoples and Land Markets in Highland Ecuador. Journal of Agrarian Change, 21 (1): 3-24

Goodwin, G. (2021b). Cerca del Rio y Lejos del Agua: Water, Autonomy, and Hope in the Ecuadorian Andes. Ioris, A (ed.) Environment and Development: Challenges, Policies, and Practices, Palgrave Macmillan

Hidalgo, JP, Boelens, R and Vos, J. (2017). De-colonizing Water. Dispossession, Water Security, and Indigenous Claims for Resources, Authority, and Territory. Water History 9: 67-85

Hoogesteger, J. (2013). Trans-forming social capital around water: Water user organizations, water rights, and nongovernmental organizations in Cangahua, the Ecuadorian Andes. Society and Natural Resources. 26 (1): 60-74.

Hoogesteger, J. (2014). Los nuevos sujetos del agua: organización social y la democratización del agua en los Andes. Quito: Abya-Yala

Hoogesteger, J. (2015). Normative Structures, Collaboration and Conflict in Irrigation; a Case Study of the Pillaro North Canal Irrigation System, Ecuadorian Highlands. International Journal of the Commons. 9 (1): 398-415.

Hoogesteger, J. (2016). NGOs and the Democratization of Ecuadorian Water Governance: Insights from the Multi-Stakeholder Platform el Foro de los Recursos Hídricos. Voluntas: International Journal of Voluntary and Nonprofit Organizations 27 (1): 166-86

Hoogesteger, J., Tiaguaro-Rea, Y., Rap, E. and Hidalgo, J. P. (2017). Scalar Politics in Sectoral Reforms: Negotiating the Implementation of Water Policies in Ecuador (1990-2008). World Development. 98: 300-309.

Isch López, E. and Zambrano, A. (2017). En torno a los resultados de la consulta prelegislativa sobre la Ley de Recursos Hidricos in Arroyo Castillo, A. and Isch López, E. (eds.) (2017). Los caminos del agua. Quito: Abya-Yala 
Jara, X., Montesdeoca, L. and Tasseva, I (2021). The Role of Automatic Stabilizers and Emergency Tax-benefit Policies during the COVID-19 Pandemic in Ecuador. UNU-WIDER Working Paper 2021/4

Joshi, A. and Moore, M. (2004). Institutionalised Co-Production: Unorthodox Public Service Delivery in Challenging Environments. Journal of Development Studies. 40 (4): 31-49

Llano-Arias, V. (2015). Community Knowledge Sharing and Co-Production of Water Services: Two Cases of Community Aqueduct Associations in Colombia. Water Alternatives. 8 (2): 77-98

Martínez Novo, C. (2014). Managing Diversity in Postneoliberal Ecuador. The Journal of Latin American and Caribbean Anthropology. 19 (1): 103

McBurney, M., Tuaza, LA, Ayol, C., and Johnson, CA (2021). Land and Livelihood in the Age of COVID-19: Implications for Indigenous Food Producers in Ecuador. Journal of Agrarian Change 1-9

McMillan, R., Spronk, S. and Caswell, C. (2014). Popular Participation, Equity and Co-Production of Water and Sanitation Services in Caracas, Venezuela'. Water International. 39 (2): 201-15

Mitlin, D. (2008). With and Beyond the State: Co-Production as a Route to Political Influence, Power and Transformation for Grassroots Organizations. Environment \& Urbanization. 20 (2): 339-360

Mitlin, D., and Bartlett, S. (2018). Editorial: Co-production - Key Ideas. Environment \& Urbanization, 30(2): 355-366

Moretto, L., Faldi, G., Ranzato, M., Rosati, F.N, Boozi, P.I., and Teller, J. (2018). Challenges of Water and Sanitation Service Co-production in the Global South. Environment and Urbanization. 30 (2)

Pacari, N. (1998). Ecuadorian Water Legislation Analyzed from the IndigenousPeasant Point of View. Boelens, R. and Davila, G. (1998). Searching for Equity: Conceptions of Justice and Equity in Peasant Irrigation. Amsterdam: Van Corcum 
Ponce, K, Vásquez, A, Vivanco, P and Munck, R. (2020). The October 2019 Indigenous and Citizens' Uprising in Ecuador. Latin American Perspectives. 47 (234): 9-19

Roca-Servat, D., Botero Mesa, M., and Correa Zuluaga, S. (2020). CommunityBased Water Provision in Colombia in Times of Covid-19. McDonald, DA., Spronk, S. and Chavez, D (eds). Public Water and Covid-19: Dark Clouds and Silver Linings. Municipal Service Project (Kingston), Transnational Institute (Amsterdam) and Latin American Council of Social Sciences (CLACSO) (Buenos Aires). 